\title{
GRADUATE RESEARCH SEMINARS: THEORY OR PRAXIS?
}

\author{
TERRY CARNEY*
}

There seems to us to be an obligation on law schools to ensure that research students, whether they be PhD, LLM by thesis or LLM by coursework, are instructed in [research techniques]. ${ }^{1}$

\section{INTRODUCTION}

Australian legal education has not devoted much attention to settling the form and content of post-graduate programs. Indeed, the very idea of a separate identity for post-graduate training is something of an oxymoron in Australia. Postgraduate degree programs were slow to develop in Australian legal education. They made their presence felt only in the mid 1970s, as masters by coursework programs were introduced at Sydney (1965), Monash (1973), and a few other law schools. ${ }^{2}$

In the design of these programs, little attention was given to systematic training in research methods or theory. The programs were introduced at a time of (comparative) plenty within the academy, and they built on very small scale thesis programs (LLM/Ph.D). In those schools where a decision was made to combine advanced coursework requirements with completion of a minor thesis, reliance was placed on the one-to-one supervisory setting as the transmission belt for that training. Indeed, by not requiring a minor thesis to be undertaken as part of the course-work programs, some schools effectively confined research training to full thesis programs (in 1986 Sydney dropped the thesis requirement for the pass $L L M){ }^{3}$

The theory underpinning all of this was that research skills were 
best conveyed through a one-to-one (master/apprentice) relationship. At its best, this model involved supervision by an experienced researcher who had acquired their own post-graduate degree by research in this manner. The lessons from that experience, and their subsequent research career, were then effectively conveyed to the candidate in the course of the supervision. At its worst however, supervision was minimal, and the skills of the supervisor were sparse or outdated. ${ }^{4}$ The personal priority accorded to research by the supervisor (and the culture of research within the supervising institution) was not necessarily high either. $^{5}$

The report of the Discipline Review in 1987 questioned some of these comfortable assumptions about post-graduate training in law. At the risk of misrepresentation of a complex set of proposals, their basic thesis was that post-graduate coursework education had drifted towards becoming advanced training in specialist (commercial) areas already covered in the undergraduate curriculum. They were particularly critical of the lack of systematic training programs in advanced research method, and the tendency to provide advanced specialised training rather than broader critical perspectives ("theoretical” issues). ${ }^{6}$

The concern about theory fell on fairly stony ground, ${ }^{7}$ and although the demand for it is high - research training is still in its infancy as law schools struggle both to define the balance between undergraduate and postgraduate responsibilities and to find the resources to back those priorities. With the introduction of an SJD (Doctor of Juridical Studies) in 1991, Sydney Law School took the opportunity to meet some of these challenges. In doing so, it deliberately elected to pursue academic goals over skill competencies: theory has been given precedence over praxis.

This paper sketches the assumptions of the Sydney model, outlines some of the details of the course which support characterising the unit in this way and assays a preliminary view about the national implications (and advantages) of electing to provide a "particular" brand of research training. 


\section{THE SYDNEY MODEL}

\section{The SJD Model}

The Sydney SJD program built on the foundations of the largest coursework masters program in the country. ${ }^{8}$ The degree requires that candidates complete 8 units of coursework, together with a 40 60,000 word dissertation. The course work units must be selected to complement the subject area of the thesis. Those coursework units must also include one (or more) of two "required courses: two newly developed units on "Legal Research" and/or "Legal Education". Both of these units may be taken for credit by LLM by coursework candidates. At their request, Ph.D (and other full thesis) candidates have been permitted (indeed encouraged) to audit these courses.

Predictably perhaps, the demand for the Legal Research unit on the part of LLM candidates has far outstripped predictions of demand: a total of 22 SJD and Masters candidates completed the course in 1991 (the first year) rising to 34 in $1992 .{ }^{9}$ Demand has been high even though the Sydney unit has strongly emphasised theoretical rather than simply "hornbook" skills. ${ }^{10}$ The assessment reflects this emphasis. Assessment is based on completion of a "research strategy" on an approved topic (approximately 4,0006,000 words: $60 \%$ ) and a critique of a strategy prepared by another member of the class (30\%). The course itself is taught over one semester, with one two hour seminar a week.

\section{Theoretical Orientation and the Assessment Regime}

The theoretical orientation of the course is clearly spelt out in the course description which states that:

"This course aims to expose students to debates about the nature, aims and techniques of legal research, including issues such as the relationship of legal research to that of other disciplines.”

While some more practical skills are built into the program, the unit is structured around developing a "strategy" for an academic thesis (or major piece of writing). Candidates seeking "advanced continuing legal education" in their professional career are generally not comfortable with this orientation. ${ }^{11}$ The course is not primarily designed to cater to any perceptions within the profession 
that graduates may be inadequately trained to cope with the demands of practice, ${ }^{12}$ though these constituencies necessarily overlap.

The assessment regime for the course is exclusively directed at the development of skills in planning and executing a thesis. While the assessment has been influenced by the North American debate about the virtues of the so called "path-finder exercise" within a course on legal research skills, ${ }^{13}$ in this instance the pathway to be located is one which has the characteristics of a good thesis. ${ }^{14}$ This is by no means coincident with the preparation of an encyclopedic literature (or case law) review in the "bibliographic" tradition advocated in some of the overseas literature.

\section{THE CURRENT PROGRAM: RUNNING TO FORM?}

The current structure of the program was largely established in $1991 .^{15}$ In this section of the paper, the seminar program will be outlined. This will not only enable the specific rationale for particular elements to be expounded, but also will allow readers to judge the adequacy or otherwise of the plan.

The current program covers three main areas:

- theories and techniques of legal research, types of legal and interdisciplinary research and, finally,

- the presentation and defence of research.

The first deals with basic concepts and techniques, the aims and methods of legal research, finding the law in hard copy materials and through the use of computer data bases (and CD-Roms), and an introduction to governmental and inter-governmental documentation. The second part deals in more detail with some selected areas of legal and inter-disciplinary research. The third part of the course deals with the presentation and justification of research, including assessment of research.

\section{The Concept of Research}

The course opens with a discussion of the nature of a "thesis", 16 the relevance of the scientific method (hypothesis testing and theory building), ${ }^{17}$ the relationship of research to legal argument, and the development of research strategies. ${ }^{18}$ Particular weight is given to literature which argues that legal research should pay more 
attention to general theoretical issues and values. ${ }^{19}$ This is a deliberate strategy aimed at unsettling the expectations carried by members of the entering class.

The next bracket of seminars is designed to expose the class to a wide range of traditional (hard-copy) research aids such as catalogues and indexes, specialist library holdings, and archival materials. It also introduces the variety of CD-Rom and on-line search facilities. The first of these classes is led by the law librarian and her staff, while the following seminar (on governmental and intergovernmental sources) is led by the government publications librarian at the Fisher library.

Apart from illustrating the range of different aids available for different purposes (especially aids to accessing specialist collections ${ }^{20}$ ), the seminars aim to demonstrate something of the uncertainty of legal research. ${ }^{21}$ They also raise the importance of understanding the strengths and limitations of new technologies, ${ }^{22}$ and the proper place for (and restrained balance in undertaking) bibliographic searches. ${ }^{23}$ Consideration is also given to less orthodox techniques, such as use of Freedom of Information legislation or parliamentary questions, ${ }^{24}$ as an aid in locating less accessible material.

The final seminar in this bracket is held in the research division of a major international law firm, where demonstrations and training is given in using CD-Rom collections of legislation, case law and other specialist aids. This class is led by a former director of research in law reform commissions, who later established the research division in question.

\section{“Legal and Interdisciplinary Research”}

The fifth week of the program develops the theme of the opening seminar, with a particular emphasis on the role of research in developing legal theory, ${ }^{25}$ such as studies associated with (or stemming from) movements such as critical legal studies, law and economics or feminist law perspectives. By way of contrast with the theoretical orientation of this seminar, the next concentrates on rehearsing traditional research techniques, including the character of the tasks presented in practice, at the bar, or in law reform agencies. This is also the occasion on which further treatment is given to researching in international law materials. ${ }^{26}$ 
The next seminar (led by a prominent socio-legal scholar), shifts the focus to a consideration of the justification for $^{27}$ and examples of interdisciplinary method, ${ }^{28}$ the place of empirical and social science research method within the legal process, ${ }^{29}$ the distinction between legal research and social science research, and general methodological issues. ${ }^{30}$ This is followed by a seminar looking at the advantages and pitfalls of evaluation research ${ }^{31}$ into legal institutions (built around consideration of a local case study), ${ }^{32}$ and the differing values and paradigms which may be adopted as the benchmarks for such evaluations. ${ }^{33}$ Closely allied with this, is a seminar exploring the nature of the research tasks presenting in law reform agencies; it draws on the experience of people who have led references, or co-ordinated research programs, and it uses case study material where possible to provide a unifying theme. ${ }^{34}$

\section{The Presentation and Defences of Research}

The final part of the course deals with the presentation and defence of research. The first seminar deals with practical issues (structuring of large amounts of material; ${ }^{35}$ how to work with outline structures; diagnosing and remedying structural problems ${ }^{36}$ as well as the various forms in which legal research may be required to be presented and the conventions which apply in those settings.

This is followed by a seminar which looks at ethical issues, such as the proper use of previous work/sources, the acknowledgment of assistance/co-authorship, ${ }^{37}$ the protection of privacy and dignity of human subjects of fieldwork observations, ${ }^{38}$ and related questions such as the special pressures associated with contract work, ${ }^{39}$ and preservation of "quality" in the face of the penchant for objective measurement of performance. ${ }^{40}$

The final seminar covers the question of how research is "refereed" and the differing criteria by which judgments may be made about the "worth" of research. ${ }^{41}$ Other topics include problems of privacy and confidentiality; the notion of "originality"; citation of work used in research, and the relationship between supervisor and candidate.

The seminar takes published or unpublished work as a "testbed" for later workshop discussion. It aims to draw together the lessons 
derived from the various topics dealt with in previous weeks.

\section{CONCLUSION}

\section{Aspirations and Options}

This paper opened by suggesting that postgraduate legal education in legal research had been characterised by its reliance on a (resource intensive) “apprenticeship” pedagogic model. It was also suggested that legal education had been remiss in failing to connect sufficiently with the world of ideas, and related disciplines. The "hornbook" model of instruction was therefore not favoured at the outset (despite its attraction for hard-pressed practitioners).

\section{Of Theses and Theory: Paradigm or Pretension?}

Sydney Law school deliberately set out to fashion a model of research training with a strongly "intellectual" bent. In doing so the school was mindful of the clear injunction to do so which was contained in the Report of the discipline review completed by the Pearce Committee. ${ }^{42}$ This harmonised with the historical position of Sydney as a school with a strong reputation for its interest in issues of legal theory. A judgement reinforced by observations such as those of the Chief Justice of the High Court that:

[T] o treat the law as a discrete set of principles in a vacuum and without a context is to misconceive its dynamic and ubiquitous nature ... the law schools must resist the temptation to become business schools, deferring to the demands of large commercial practices and ignoring consideration of intellectually demanding questions posed by the traditional subjects as well as the larger and enduring jurisprudential issues relating both to the structure of legal systems and to the law's role in society. ${ }^{43}$

But it is one thing to chart directions and another to ensure that they are realised. It would be presumptuous to claim that the Sydney model of a post-graduate Legal Research unit manages to fully achieve the ambitious goals which it has set. In common with many Australian law schools, we are all too aware of the dangers of complacency.

\section{Traps for Potential “All-rounders”?}

In an era where the resources available to Law schools are finite 
(and contracting), there is likely to be a temptation to see such courses as a panacea for deficiencies in postgraduate supervision generally. This would be a serious mistake. In the writer's opinion, a properly designed unit can only be a supplement to a properly organised program for selecting and supporting post-graduate students in the formulation and execution of individually supervised research projects. It cannot provide a (less resource intensive) alternative to a quality program of post-graduate training.

Several conclusions would appear to follow from this. First, post-graduate legal education cannot be provided on the cheap: institutions must make deliberate choices about the relative priority to be given to undergraduate and postgraduate education. To fail to do so will inevitably lower the standard of the post-graduate program (and may lower the quality of the undergraduate program as well).

Second, a postgraduate unit on legal research cannot correct for deficiencies in other parts of the program (all postgraduate coursework units bear a responsibility to inculcate and improve skills in legal research and writing). Failure to appreciate this will lead to the presentation of (so-called) "advanced" (or "specialised") courses as a sufficient basis for award of post-graduate qualifications: something that can only devalue the currency (whatever it is called, advanced continuing education is just that).

\section{A Case for Differentiation?}

These are not matters of idle speculation. Resource constraints are bearing all too heavily on legal education at the present. So heavily, that — with some notable exceptions ${ }^{44}$ — institutions have become transfixed by a single institutional paradigm of a law school. Instead of sharpening the points of difference between their educational profiles and programs, most Law Schools appear to be seeking to replicate (historic) models of the "all-rounder". ${ }^{45}$

This paper unapologetically argues the case for staking out some of the ground which would identify Sydney Law school and others who may follow suit - with a particular brand of research training. They would gain a reputation as institutions which attach a high priority to fostering research skills notable for their strong theoretical, inter-disciplinary and "academic" (or reflective) character. But this is by no means the only (nor 
necessarily the "best") model. Moreover, the task of defining (and refining) objectives must be an ongoing one - institutions must remain responsive to changing conditions.

\section{An Invitation to a Discourse}

Of course all this rather begs both the question of the appropriateness of the choice of theory ahead of praxis, and the question of the degree to which the program realises the objectives which Sydney law school has set for itself in designing an initial SJD unit on legal research.

This paper has sketched one possible framework for such a course. The object has been two-fold: to locate the course in a "perspective", and in so doing, to provide a basis for dialogue about the objectives and methods which might be set for such a unit. It is an answer to the challenge to, "put your discourse into some frame, and start not so wildly from my affair." 46

The frame for the discourse may be contested, and the perspective outlined here may yet cause readers to "start" from our affair. But the invitation to engage in a dialogue remains.

* Sydney University Law School. A revised version of a paper presented at the Australian Law Teachers Association conference "Legal Change”, Brisbane, Queensland University of Technology, 9-12 July 1992. The author wishes to acknowledge the research assistance provided by Ms A Duffield. Needless to say, the author accepts full responsibility for the contents of the paper.

(C) 1993. (1993) 4 Legal Educ Rev 165.

1 Commonwealth Tertiary Education Commission, Australian Law Schools - A Discipline Assessment for the Commonwealth Tertiary Education Commission vol 1, ch 6, 234 (Canberra: AGPS, 1987) (referred to as Pearce Report).

2 The same was true in Canada and the UK. Pearce Report, supra note 1 at 231.

3 Pearce Report, supra note 1 at 238. The Committee went on to observe that "we would not see the passing of exams in 4 subjects, albeit year long subjects, as a sound basis for the award of an LLM. we are of the view that there should be a substantial written component in the assessment for an LLM. This might be included in the subjects themselves or take the form of a dissertation or comprise both. We are therefore disturbed to find that Sydney has abolished its dissertation requirement.” Id at para 6.21.

$4 \quad$ I Moses, Supervising Postgraduates (Kensington: Higher Education Research and Development Society, 1985) 4 (a quarter of all candidates report dissatisfaction with supervision).

5 See also I Moses, Academic Staff Evaluation and Development (St Lucia: University of Queensland Press, 1988) 45 (describing the mix of teaching and research). Id at 95 (describing the research culture of the institution). Pearce Report, supra note 1 at 237, 242.

7 Monash Law School amended its regulations in 1988 to require that candidates for the coursework LLM should for undertake at least one "theory" unit, but this was reversed, without ever having been implemented, in 1990, in part because 
of perceived opposition from the student body.

8 At the time of writing Sydney reported the following post-graduate enrolment levels: 477 Master of Laws by coursework, 103 Master of Taxation, 25 Master of Criminology, 50 Master of Labour Law and Relations, 12 Master of Laws by major thesis, 24 Doctor of Juridical Studies and 20 Doctor of Philosophy. See, Faculty of Law, University of Sydney, ALTA Report 1992, 7 (unpublished).

9 Research training at the undergraduate level has not been a notable strength of Australian legal education; Sydney does not have a minor thesis requirement for an LLB (Hons), and until recently, did not mandate a major piece of writing for the LLM by coursework (even the LLM (Hons) program has been queried for according insufficient attention to the supervision of the required "By-laws" dissertations.

10 Compare $\mathrm{T}$ Hutchinson, Hornbooks, Slipsheets and Pocket Parts; Legal Research and Writing in a University Library (1991) (unpublished manuscript, Queensland University of Technology).

11 Candidates with other expectations either do not enrol or withdraw at an early stage: the 1992 class shed 14 members for instance (some of these were candidates who deferred the unit while completing other coursework; but some withdrew because their interests were less academic).

12 See J Howland \& N Lewis, The Effectiveness of law School Research Training Programs (1990) $40 \mathrm{~J}$ Legal Educ 381. For a rebuttal of some of these arguments, see, T Hardy, Why Legal Research Training is So Bad (1991) $41 \mathrm{~J}$ Legal Educ 221 (arguing that the training may be adequate for all except the elite firms).

13 See further R Berring \& K Vanden Heuvel, Legal Research: Should Students Learn It or Wing It? (1989) 81 L Lib J 431, at 446-447 (describing Boalt Hall “Pathfinder exercises”). Compare C Wren \& J Wren, Reviving Legal Research: A Reply to Berring and Vanden Heuvel (1990) 82 L Lib J 463, at 487-491. In this the exercise seeks to refine most of the elements expected in a good extended outline of a thesis proposal, but adds requirements to critically consider the alternative strategies and methodologies which might be deployed. Compare Moses, supra note 4 at 13-17.

15 The course was CO-taught by James Crawford and the author in that year. A revised program, taking into account student responses, was offered by the author in 1992.

16 See J Bell, Doing Your Research Project: A Guide for First-Time Researchers in Education and Social Science (Milton Keynes: Open University Press 1987); J Campbell, R Daft \& C Hulin, What to Study: Generating and Developing Research Questions (London: Sage, 1982).

17 C Mills, On Intellectual Craftsmanship, in C Mills ed, Sociological Imagination (New York: Grove Press, 1961).

18 E Ellinger \& K Keith, Legal Research Techniques and Ideas (1978) $10 U$ Wellington L Rev 1-8.

19 See for example, T Daintith, Legal Research and Legal Values (1989) 52 Mod L Rev 352-368; J Mohr, Law and Learning Revisited: Discourse, Theory and Research (1987) 25 Osgoode Hall LJ 671-700; P Ziegler, A General Theory of Law As A Paradigm For Legal Research (1988) 51 Mod L Rev, 569-592.

20 I Duncan, Guide to the Australian Government Publications (Sydney: University of Sydney Library, 1989); I Duncan, Guide to the British Government Publications (Sydney: University of Sydney Library, 1989); I Duncan, Guide to United States Government Publications (Sydney: University of Sydney Library, 1989); I Duncan, Guide to the Publications of the European Communities (Sydney: University of Sydney Library, 1989); I Duncan, Guide to International Governmental Organizations (Sydney: University of Sydney Library, 1989). 
R Reusch, The Search for Analogous Legal Authority: How to Find it When You Don't Know What You are Looking For (1984) 4 Legal Ref Serv Q 33-38.

22 M Cohen, Research in a Changing World of Law and Technology (1990) 13 Dalhousie LJ 5-19.

23 Compare C Wren \& J Wren, The Teaching of Legal Research (1988) 80 L Lib J 7-61.

24 A Bryman ed, Doing Research in Organizations (London: Routledge, 1988)

25 R Berring, Legal Research and Legal Concepts: Where Form Molds Substance (1987) 75 Cal L Rev 15-27; A Hunt, Sociological Movement in Law (London: Macmillan, 1978); Symposium, Critical Legal Studies (1987) 14 JL \& Soc’y (No 1).

26 J Williams, Research Tips in International Law (1981) 15 Intl L \& Econ 321; J Williams, Undertaking Effective Research in International Law (1983) 17 Int'l L 381-390.

27 Mohr, supra note 19.

28 C Campbell \& P Wiles, The Study of Law and Society in Britain (1976) 10 L \& Soc'y Rev, 547-578.

29 N Channels, Social Science Methods in the Legal Process (Totowa, New Jersey: Rowman \& Allanheld, 1985).

30 M MacLean, Methodological Issues in Social Surveys (London: MacMillan, 1979); H Kincaid, Defending Laws in the Social Sciences (1990) 20 Phi1 Soc Sci 56-83.

31 P Rossi, Testing for Success and Failure in Social Policy, in P Rossi \& W Williams, Evaluating Social Programs: Theory, Practice and Politics 11-58 (New York: Seminar Press, 1972); C Weiss, Utilisation of Evaluation: Towards Comparative Study, in C Weiss, Evaluating Action Programs (Boston: Allyn \& Bacon, 1972); C Weiss \& M Rein, The Evaluation of Broadaim Programs: A Cautionary Case and a Moral [19691 Annals Am Academy Pol \& Soc Sci 385.

32 T Carney \& D Tait, Balanced Accountability: An Evaluation of the Victorian Guardianship and Administration Board (Melbourne: Office of Public Advocate, 1991).

33 T Carney, Client Assessments of Victoria’s Guardianship Board (1989) 15 Monash UL Rev 229-252; T Carney, The Limits and the Social Legacy of Guardianship in Australia (1989) 18 Fed L Rev 231-266; T Carney \& P Singer, Ethical and Legal Issues in Guardianship Options for Intellectually Disadvantaged People (Canberra: AGPS, 1986).

34 T Carney, Reforming Child Welfare: Diverting By-ways on the Road to Utopia (1985) 18 Aust \& NZJ Crim 237-256, T Carney, Law at the Margins 112-125 (Melbourne: OUP, 1991); M Hakel, M Sorcher, M Beer \& J Moses, Making it Happen: Designing Research with Implementation in Mind (London: Sage, 1982); A Majchrzak, Methods for Policy Research (Beverly Hills: Sage, 1984).

D Steinberg, How to Complete and Survive a Doctoral Dissertation (London: St Martin's Press, 1981).

K Howard, Management of a Student Research Project (Aldershot, Hants: Gower, 1983); R Berry, How to Write a Research Paper (Oxford: Pergamon, 1986).

37 D Papay-Carder, Plagiarism in Legal Scholarship (1983) 15 U Toledo L Rev 233-269; Re La Trobe University [1987] VR 447.

38 The Australian Vice-Chancellors' Committee produced "Guidelines for Responsible Practice in Research ...” in November 1990 (incorporating a "Code of Conduct for the Responsible Practice of Research") which is used as a benchmark on many of these issues.

39 R Wild, Some Problems of Contract Research in Sociology (1985) 21 Aust \& NZ J Soc'y 258-266. 
40 D Vernon, Ethics in Academe — Afton Dekanal (1984) 34 J Legal Educ 205214.

41 D Le Grew, Pursuing Productivity, Excellence and Other Research Snarks: A Critique of Current Attitudes (1984) 27 Vestes 39-43; L West, T Hore \& P Boon, Publication Rates and Research Productivity (1980) 23 Vestes 32-37.

42 Pearce Report, supra note 1.

43 A Mason, Inauguration of the Faculty of Law at the University of Wollongong (1991) 34 Aust U Rev 24, at 24.

44 Griffith, Murdoch and perhaps La Trobe Universities are possible (refreshing) exceptions to this proposition.

45 M Le Brun, Curriculum Planning and Development in Law in Australia: Why is Innovation so Rare? (1991) 9 Law in Context 27-46.

46 W Shakespeare, Hamlet (Act III, scene ii, 325). 